\title{
TÓTH ORSOLYA
}

\section{Symmachus: Levelek Praetextatushoz}

\begin{abstract}
A 4. századi római arisztokrácia világába engednek bepillantást Symmachus azon levelei, amelyeket Vettius Agorius Praetextatushoz írt. A nagy tiszteletnek örvendó senator, a régi római vallás egyik legnagyobb védelmezöje Symmachus mentora és kedves barátja volt. A hozzá szóló levelek, amelyek képet adnak a korszak előkelőinek elfoglaltságairól, életmódjáról és mentalitásáról, először jelennek meg jegyzetekkel kísért magyar fordításban. ${ }^{1}$
\end{abstract}

Kulcsszavak: Symmachus, Praetextatus, római arisztokrácia, pogány vallásosság, késő antikvitás

\section{Bevezető}

A 4. század második felében élt kiváló szónok és befolyásos politikus, Quintus Aurelius Symmachus² fennmaradt levélgyüjteményében az amicus és az amicitia szavak összesen 338-szor fordulnak elö, ami nagyon nagy szám: ennél gyakrabban csak az officium említése történik 351 előfordulással. ${ }^{3}$ Ez egyértelmúen jelzi, milyen lényeges szerepet töltött be életében a barátság. Barátainak nagy száma a kapcsolati háló rendkívüli

\footnotetext{
${ }^{1}$ A tanulmány alapjául szolgáló kutatást az „Emlékezetkultúra az antikvitástól a modernitásig" Kutatócsoport 20684B800 témaszámú, a Károli Gáspár Református Egyetem Bölcsészet- és Társadalomtudományi Kara által finanszírozott pályázat keretében végeztem. 2 Symmachus (szül. 340-345 között, megh. 402) consul 391-ben, a késő római arisztokrácia kimagasló alakja. Tíz könyvből álló levélgyűjteményének első kötetét saját maga szerkesztette. A gyưjtemény első kilenc könyve magánleveleket tartalmaz, tizedik kötetében pedig hivatalos levelek találhatóak. Apjával folytatott levelezésének jegyzetekkel kísért magyar fordítását ld. TÓTH (2020).

${ }^{3}$ A számításokat közreadja: MitcheLL (2016: 179).
} 
fontosságának indikátora is, s közöttük az egyik legjobb barát Praetextatus.

Vettius Agorius Praetextatus (315 körül-384 decembere) korának nagy tiszteletben álló arisztokratája, a régi római erkölcsök megtestesítője, a pogány előkelők csoportjának kiemelkedő képviselője volt. Politikai karrierje során többek között betöltötte a proconsul Achaiae hivatalát, ${ }^{4}$ 367-368-ban praefectus urbi volt, 384-ben pedig a praefectus praetorio Illyrici, Italiae et Africae tisztséget viselte, ${ }^{5}$ s ugyanebben az évben consul designatus lett, azonban meghalt, mielőtt a consuli hivatalt betölthette volna. Praefectus urbiként végzett tevékenységéről Ammianus Marcellinus a következőket írja:

Időközben Praetextatus példásan igazgatta Rómában praefectusi hivatalát... Tekintélyével és a valóságon alapuló igazságos döntéseivel lecsillapította azt a nyugtalanságot, amit a keresztények viszálykodásai támasztottak. Ursinus ${ }^{6}$ eltávolítása után helyreállt a teljes békesség, amely tökéletesen megfelelt a római polgárok akaratának. A kiváló férfiú népszerűsége pedig sok célszerü intézkedés folytán egyre növekedett. Elhordatott minden erkélyt, amelyeknek építését már a régi törvények is tiltották, lebontatta a magánházaknak azokat a falait, amelyek a szent épületekhez szemérmetlenül hozzá voltak építve. Végül minden városrészben hiteles súlyokat rendszeresített, mivel másképp nem lehetett gátat vetni sok ember kapzsiságának, akik a saját kényük-kedvük szerint

4 362-ben, Mamertinus és Nevitta consulsága idején. Hivatalviseléséről Ammianus Marcellinus is megemlékezik: Aderat his omnibus Praetextatus, praeclarae indolis gravitatisque priscae senator, ex negotio proprio forte repertus apud Constantinopolim, quem arbitrio suo [sc. Iuliano] Achaiae proconsulari praefecerat potestate. (Amm. Marc. 22, 7, 6).

${ }^{5}$ Vö. Cod. Theod. 6, 5, 2.

${ }^{6}$ Ursinus ellenpápáról van szó, aki 366-367-ben I. Damasusszal egyszerre birtokolta a legfőbb papi méltóságot. A két főpap támogatói között odáig fajult az ellenségeskedés, hogy a rend helyreállítása érdekében Ursinust számüzni kellett. Praetextatus szerepéről az ügyben részletesen ld. KAHLOS (1997: 41-54). Edward J. WATTS (2015: 142) az utolsó pogányokról szóló monográfiájában összehasonlítja, hogyan kezelte ezt az ügyet Praetextatus és hivatali elődje, a pannoniai származású Viventius: míg utóbbinak nem sikerült elkerülnie a vérontást, és végül saját épsége érdekében el kellett hagynia a várost, addig Praetextatus rendkívül gyorsan és hatékonyan oldotta meg a problémát bizonyítva társadalmi kapcsolatainak erejét és saját rátermettségét a pozíciójára. 
készítettek maguknak mértékeket. A peres ügyek vizsgálatával kapcsolatban mindenkinél jobban megvalósította azt, amit Cicero mondott Brutus dicséretére: noha nem tett semmit kedvezésből, mégis minden cselekedete üdvösnek látszott. ${ }^{7}$

Egy dedikációs feliratból ${ }^{8}$ arról is értesülhetünk, hogy az Ammianus által említett munkálatok mellett helyreállíttatta a Porticus deorum consentiumot a Forum Romanumon: ez nemcsak hivatali kötelezettségeivel állt összhangban, de szimbolikus, szakrális jelentőséggel is bírt a régi római vallásosság szempontjából. ${ }^{9}$ Később praefectus praetorióként sikerült elérnie a császárnál, hogy az kiadjon egy rendeletet, amely megvédi a régi középületeket a rablásoktól és fosztogatásoktól. ${ }^{10}$

A praefectus urbi és a praefectus praetorio tisztségek betöltése közötti 16 évben semmilyen közéleti hivatalt nem viselt, ami talán szokatlannak tünhet, azonban tagja volt több császári követségnek is. A senatus által a császárhoz küldött követek szerepe igen jelentős volt a korban, amit az is alátámaszt, hogy rendre találkozunk említésükkel a különböző feliratokon. Így Praetextatus esetében is az Aventinuson talált felirat ${ }^{11}$ és sírfelirata $^{12}$ egyaránt politikai karrierje részének tekinti legatusi szerepét:

\footnotetext{
${ }^{7}$ Amm. Marc. 27, 9, 8-10. Ford. SZEPESY Gyula.

${ }^{8}$ CIL VI 102 = ILS I 4003: [Deorum c]onsentium sacrosancta simulacra cum omni lo[ci totius adornatio]ne cultu in [formam antiquam restituto] [V]ettius Praetextatus, v(ir) c(larissimus), pra[efectus u]rbi [reposuit] curante Longeio [--- v(ir) c(larissimus, c]onsul[ari].

${ }^{9}$ Erről bővebben ld. KAHLOS (1995: 41-43), valamint MACHADO (2006: 169-170).

10 Vö. MATTHEWS (1975: 210). Ebben az évben épp Symmachus volt a praefectus urbi, aki rögtön meg is kezdte a rendelet végrehajtását, amelynek során több keresztény fosztogatót bebörtönöztek, az uralkodó azonban ezt nem nézte jó szemmel és kötelezte őt a foglyok szabadon bocsátására.

${ }^{11}$ Praetextatusnak két háza volt Rómában, az egyik az Esquilinus dombon állt, hatalmas kertjei a mai Termini pályaudvarig nyúltak, a másik az Aventinuson volt, utóbbi területéről került elő a szóban forgó felirat. CIL VI 1777 = ILS I 1258: Vettio Agorio Praetextato v. c. et inl., correctori Tusciae et Umbriae, consulari Lusitaniae, proconsuli Achaiae praef. urb., praef. praetorii Illyrici Italiae et Africae cons. designato, legato amplissimi ordinis septies et ad impetrandum reb. arduis semper opposito, parenti publice privatimq. reverendo [...].

${ }^{12}$ CIL VI 1779 = ILS I 1259: d. m. Vettius Agorius Praetextatus... in [r]e publica vero quaestor candidatus, pretor urbanus, corrector Tusciae et Umbriae, consularis Lusitaniae, proconsule Achaiae praefectus urbi, legatus a senatu missus $V$, praefectus praetorio II Italiae et Illyrici, consul ordinarius designatus [...].
} 
előbbi szerint hétszer, epitaphiuma szerint ötször járt különböző ügyekben követségben a császárnál. Az egyik ilyen, sikeres követjárásra 370 körül került sor, ennek célja az volt, hogy meggyőzzék Valentinianust: ne lehessen senatorokat kínvallatásnak alávetni, és ne szabjanak ki az elkövetett bünhöz képest aránytalanul nagy büntetést. Az ügy előzménye az volt, hogy Maximinus praefectus annonae magához ragadva a bíráskodási jogkört a praefectus urbitól, a beteg Olybriustól, hatalmát arra használta, hogy mágia, méregkeverés, házasságtörés vádjával és egyéb indokokkal minél több előkelő vesztét okozza. Tevékenységét az uralkodó is jóváhagyta, azonban a követség határozott fellépésére visszavonta a Maximinust támogató rendelkezését. ${ }^{13}$

Azt nem mondhatjuk tehát, hogy a fentebb említett hosszú időintervallumban Praetextatus teljesen távol maradt a közélet eseményeitől, azonban az bizonyosnak látszik, hogy idejének nagyobb részét vidéki elvonultságban, birtokain töltötte - saját elmondása szerint - élvezve az otiumot és a vadászatot, Symmachus szerint viszont inkább „a régiek könyvein kérődzve."14 A Rómától távol lévő Praetextatus Symmachus leveleiben rendre úgy jelenik meg, mint aki minden szabadidejét az irodalomnak és a filozófiának ${ }^{15}$ szenteli, s ez a kép élhetett róla a közvetlen utókorban is. Az 5. század első felében alkotó Macrobius lakomabeszélgetésének, a Saturnaliának ő az egyik főszereplője mint korának emblematikus figurája. Macrobius szerint Praetextatus rendkívüli műveltséggel rendelkező férfiú, aki szinte minden tudományterületen szakértő, de különösképpen kimagasló ismeretekkel rendelkezik a régi római vallást illetően. A kiváló tudós képe már a mű elején megalapozásra kerül azzal, hogy a képzeletbeli lakoma alkalmával Praetextatus a könyvtárában fogadja vendégeit, akik egyébként szintén előkelö és nagy müveltségü

\footnotetext{
${ }_{13}$ Amm. Marc. 28, 1, 24-25.

14 Symm. Ep. 1, 53, 1: Otio et venatibus gloriare. Est haec quidem iucunda iactatio sed ludo magis a te prolata quam serio. Nam remissa tempora et ab negotiis publicis feriata libris veterum ruminandis libenter expendis.

15 Praetextatus írásai nem maradtak fenn, de tudomásunk van róla, hogy görögről latinra fordította Aristotelés Első és Második Analitikájának Themistius által készített kivonatait. Vö. KAHLOS (1994: 14, 4. jz).
} 
emberek: a civitatis nostrae lumina, ${ }^{16}$ a doctorum doctissimi ${ }^{17}$ és más hasonló kifejezésekkel kerülnek bemutatásra.

Az előkelőség és a müveltség hangsúlyozása igen fontos Macrobius számára, s Praetextatus felesége, Paulina is elsőként ezt a két dolgot méltatja férjével kapcsolatban közös sírfeliratukon. Fabia Aconia Paulina, Fabius Aconius Catullinus Philomathius lánya, negyven évig élt házasságban Praetextatusszal. Költői tehetséggel is megáldott, művelt asszony volt, aki férjéhez hasonlóan elkötelezett volt a régi római vallás és kultuszai fenntartása iránt. Rómában előkerült egy márvány szobortalapzat (jelenleg a Capitoliumi Múzeumban őrzik), amelyen egykor minden bizonnyal Praetextatus szobra állt, s amely talapzatnak mind a négy oldalán feliratok olvashatók: az elülső oldalon Praetextatus cursus honoruma, továbbá az ô és felesége papi tisztségei, a jobb és bal oldalon verses felirat emlékezik meg Paulináról, ${ }^{18}$ míg a hátoldalon egy 41 soros vers Praetextatust méltatja. ${ }^{19}$ Ez utóbbit Paulina írta, valószínűleg a halotti beszéd alapján, amelyet férje fölött tartott. ${ }^{20} \mathrm{Az}$ asszony elhunyt férjét doctusként jellemzi megemlítve, hogy az irodalmat és a filozófiát prózában és lírában egyaránt tanulmányozta latin és görög nyelven is. Praetextatus görögtudását azért is tarthatta fontosnak kiemelni, mert e nyelv ismerete a korszak nyugati kultúrájában már egyáltalán nem számított természetes dolognak a müvelt emberek körében sem. Paulina szerint férje bármit olvasott, azt továbbfejlesztette: vel quae periti condidere carmina, / vel quae solutis vocibus sunt edita, / meliora reddis quam legendo sumpseras. Ez utalhat arra, hogy Praetextatus a kor más müvelt arisztokratáihoz hasonlóan, miközben olvasta és másolta az egyes kéziratokat, javította is őket, de vonatkozhat filozófiai kommentárjaira is, vagy általánosabb értelemben a müveltségére, vagyis nemcsak passzív befogadó-

\footnotetext{
16 Sat. 1, 2, 16.

17 Sat. 7, 3, 1 .

${ }^{18}$ A felirat mélyen vallásos nőként mutatja be Paulinát, aki ideális feleség és ideális római. Férjét mindig saját maga elé helyezte, azonban még férjénél is fontosabb volt számára Róma sorsa: Paulina, veri et castitatis conscia, / dicata templis atq. amica numinum, / sibi maritum praeferens, Romam viro, / pudens, fidelis, pura mente et corpore [...].

${ }^{19}$ CIL VI 1779 = ILS I 1259. A feliratok részletes bemutatását és elemzését ld. KAHLOS (2002).

${ }^{20}$ Vö. KAHLOS (1994: 16-17).
} 
ja volt olvasmányanyagának, hanem a korábbi szerzők műveinek tanulmányozásával és interpretálásával új értéket teremtett.

Az irodalomban és a tudományokban való jártasság nagyon lényeges, mégis Paulina szerint apróságnak számít Praetextatusnak a szent dolgokra, a vallási misztériumokra vonatkozó titkos tudásához képest: sed ista parva: tu pius mystes sacris teletis reperta mentis arcano premis divumque numen multiplex doctus colis. A Saturnaliában is a vallási kérdések legnagyobb szakértőjeként jelenik meg. Beszélgetőtársai princeps religiosorumnak (Sat. 1, 11, 1), omnium sacrorum praesulnak (Sat. 1, 17, 1) nevezik, ő az egyetlen, aki minden, a vallással kapcsolatos kérdésre tudja a választ: sacrorum omnium Vettius unice conscius (Sat. 1, 7, 17). Ez az oka annak, hogy ő beszél egy igen hosszú fejezetben a napkultuszról, majd később a pontifexi jogról Vergilius kapcsán, az ünnepek és a különböző rítusok eredetét is ő ismeri, éppúgy, mint az istenek titkos természetét.

Praetextatus hivatali tisztségeit számban felülmúlták a vallással kapcsolatos funkciói. Számos papi tisztséget viselt: többek között volt pontifex Vestae és pontifex Solis, augur, Liber papja, és az eleusisi misztériumokba is beavatást nyert. ${ }^{21}$ Hasonlóképpen felesége is különböző misztériumvallások beavatottja volt, ezek táplálhatták a halál utáni életbe vetett hitét, amely annak reményével töltötte el, hogy távozása után e világból újra találkozhat majd férjével. ${ }^{22} \mathrm{Ez}$ a rendkívül aktív részvétel a hagyományos római vallás kultuszaiban a házaspár részéről közösségi identitásuk legmarkánsabb jellemzője, s ezt hangsúlyozzák a személyükhöz köthető feliratos emlékek is. Sírfeliratuk tanúsága szerint Praetextatus és Paulina számára a földi javak és a világi tisztségek nem képviseltek különösebb értéket. A laudatio funebris hagyományában a közéleti karrier eredményeinek felsorolása képezi a legfontosabb részt, Paulina azonban ezt elintézi egyetlen rövid mondattal, egyértelmüen jelezve, hogy Praetextatus a hivatali tisztségeket illékony, jelentéktelen

\footnotetext{
${ }^{21}$ ILS I 1259: d. m. Vettius Agorius Praetextatus augur, p[o]ntifex Vestae, pontifex Sol[is], quindecemvir, curialis Herc[u]lis, sacratus Libero et Eleusi[ni]s, hierophanta, neocorus, tauroboliatus, pater patrum [...] et Aconia Fabia Paulina c. f., sacrata Cereri et Eleusiniis, sacrata apud Eginam Hecatae, tauroboliata, hierophantria. Hi coniuncti simul vixerunt ann. XL. ${ }^{22}$ Vö. CIL VI 1779 = ILS I 1259, 40-41. Paulina egyébként nem sokkal élte túl férjét.
} 
dolgoknak tartotta. ${ }^{23}$ Symmachus abban a relatiójában, amelyben arra kéri az uralkodókat, engedélyezzék tiszteleti szobrok felállítását a megboldogult Praetextatus számára, magasztalja az elhunyt erényeit és azt mondja róla, bár halandó ember volt, a világi javakat és a test örömeit megvetette: non quod ille praemia terrena desideret, qui gaudia corporis, etiam cum hominem ageret, ut caduca calcavit. ${ }^{24}$ Symmachus szavai: praemia terrena et gaudia corporis ut caduca calcavit szépen egybecsengenek a sírversben olvasható kijelentéssel: honores aut potestates hominumque votis adpetita gaudia caduca et parva semper autumans, s a kettő minden bizonnyal nem független egymástól. Egy későbbi mondatában is azt mondja Symmachus: ille, quem semper invitum secutus est honor [...]. Hasonlóképpen nyilatkozik róla Ammianus Marcellinus is, aki szerint Praetextatus nem kereste a közéleti sikereket, ut cum nihil ad gratiam faceret. ${ }^{25} \mathrm{Az}$ említett relatióban Symmachus így folytatja barátja dicséretét: in alios temperatus, in se severus, sine contemptu facilis, sine terrore reverendus [...]. ${ }^{26} \mathrm{~A}$ szerénység és a másokkal szemben tanúsított mértékletes viselkedés a $S a$ turnalia Praetextatusának is egyik jellemző vonása: ő az ideális házigazda, aki minden vendégével egyaránt kedvesen bánik, s jóllehet kora és jelleme folytán a legnagyobb tekintéllyel rendelkezik, ezt a többiekkel soha nem érzékelteti. Ammianus tudósításából ugyanakkor azt is tudjuk, hogy ez a szelíd viselkedés nem jelentett gyengekezűséget: „A becsületesség és a feddhetetlenség különféle példáival, amikkel már kora ifjúságától fogva hírnévre tett szert, elérte azt - ami ritkaság -, hogy féltek ugyan tőle, mégsem vesztette el polgártársai szeretetét, pedig az nemigen szokott lángolni a szigorú elöljárók iránt." ${ }^{27}$ - jellemzi ôt a történetíró.

Mint azt korábban láthattuk Symmachus méltató szavai kapcsán, Praetextatus nem csak másokkal, de önmagával szemben is severus, vagyis szigorú volt, amit felfoghatunk a hagyományos római erények

\footnotetext{
${ }^{23}$ quid nunc honores aut potestates loquar hominumque votis adpetita gaudia? quae tu caduca ac parva semper autumans divum sacerdos infulis celsus clues.

${ }^{24}$ Rel. 12, 2.

${ }^{25}$ Amm. Marc. 27, 9, 10.

${ }^{26}$ Rel. 12, 3. A barátjára jellemző rendkívüli szerénységre egyik levelében is utal: Ep. 1, 55.

27 Amm. Marc. 27, 9. Ford. SZEPESY Gyula.
} 
egyikének kifejeződéseként, de az aszketizmusra való hajlam jeleként is. ${ }^{28}$ A Paulina által fogalmazott sírvers azt mondja, hogy Praetextatus azon bölcsek írásait tanulmányozta, akik számára nyitva áll az ég kapuja. ${ }^{29}$ A késő antikvitásban nemcsak a misztériumvallásoknak tulajdonítottak kiemelt fontosságot, hanem a filozófia lélek halhatatlanságával foglalkozó tanainak is. Más sírfeliratokat is ismerünk a korszakból, amelyek az elhunyt erényeként annak müveltségét és filozófiai ismereteit említik. A mulandó földi dicsőség és a világi örömök megvetése könnyebben érthető az ebben az időben jelentkező aszketikus áramlatok ismeretében, amelyek igen elterjedtek voltak az értelmiségi körökben, s amelyeket a test és lélek ellentétét hangsúlyozó orphikus, pythagoreus, platonikus és újplatonikus nézetek befolyásoltak.

Symmachusnak tizenkét, Praetextatushoz írott levele ismeretes, ezek levélgyüjteménye első könyvében találhatóak, 44-55 közötti sorszámmal. A legkorábbiak - szerzőjük életkorából kikövetkeztethetően - nem keletkezhettek 360/365 előtt, ${ }^{30}$ a legkésőbbi pedig 384-ből, Praetextatus halálának évéből való. Symmachus nagyjából 30 évvel volt fiatalabb levelezőpartnerénél, hogy mégis szoros barátság alakulhatott ki közte és a között a Praetextatus között, aki inkább Avianius Symmachusszal, a szónok apjával tartozott egy generációba, annak több oka is lehet. Bizonyos, hogy Praetextatus már régebb óta barátságban volt a Symmachus-

${ }^{28}$ A Saturnaliában Praetextatus és társai mértékletes módon fogyasztják ételeiket, és csak kicsiny pohárkákból iszogatva, józanságukat megőrizve beszélgetnek. A szerény ételek és mérsékelt borfogyasztás egyébként is csupán kiegészítői annak az igényes társalgásnak, amely a lakoma lényegét képezi. Macrobius szereplőinek többsége számára a decens és méltóságteljes viselkedés egy kötetlen baráti beszélgetés során is alapvető elvárás. A mérték nem csupán az étel- és italfogyasztás tekintetében játszik jelentős szerepet, hanem a beszédben, a társalgásban is, olyannyira, hogy még csak egy hangos kacagásra sem találunk példát az egész müben, ők nullo admixtu voluptatis ünnepelnek. (FLAMANT [1977: 191] a szereplők humortalan, a komikus elemet teljességgel mellőző viselkedését az angol arisztokrácia magatartási szokásaihoz hasonlítja.) A sobrietas és az abstinentia kifejezések legalább olyan gyakran fordulnak elő a beszélgetés megfelelő módja, mint az étkezés kapcsán. (Erre példa többek között Praetextatus azon indítványa, miszerint az összejövetel résztvevői sobriis fabulis [Sat. 1, 5, 11] szórakoztassák egymást.)

29 [...] cura soforum, porta quis caeli patet [...].

30 SALZMAN (2011: 93) így hivatkozik rájuk, míg CALLU (2003) jóval későbbre, 376-ra teszi az első episztolákat. 
családdal, ezt támasztja alá az 1. könyv 50. levele, amelyben Symmachus játékos féltékenységgel azért ostorozza barátját, amiért az nem átallott egyazon levelet küldeni neki és apjának. ${ }^{31} \mathrm{~A}$ felháborodást mímelö, rendkívül közvetlen, szinte már pimasz stílus is a köztük lévő szoros barátság jeleként értelmezhető, csakúgy, mint az 55. levélben a testvéri szeretetre történő hivatkozás: Scio germani amoris esse, quod suades. ${ }^{32} \mathrm{~A}$ Symmachus atyjával való jó kapcsolatra utal a 44. levél is, amelyben a szónok beszámol apja aktuális ügyeiről Praetextatusnak. Ehelyütt nem valamiféle jelentéktelen dologról van szó, hanem arról értesíti idősebb barátját örvendezve, hogy a senatus visszahívta a városba vidéki elvonultságban élő atyját, aki ezért január elsején köszönőbeszédet tartott a tanács előtt. ${ }^{33}$ A levelek tanúsága szerint Praetextatus nemcsak Symmachus apját, de testvérét, Celsinus Titianust is jól ismerte és támogatta, tehát a családi kapcsolat biztosan közrejátszott a barátság kialakulásában. ${ }^{34}$ Titianus egyébként 380-ban meghalt, és fennmaradt az a levél is, ${ }^{35}$ amelyben Symmachus elpanaszolja bánatát Praetextatusnak, akinek vigaszára számít.

$\mathrm{Az}$ is bizonyosnak látszik, hogy Symmachus mentoraként, vagy egyfajta mestereként tekintett Praetextatusra, akivel gyakran megvitatta elsősorban a vallási kérdésekben felmerülő problémáit, illetve véleményeztette szónoki beszédeit. Ezt támasztja alá a 44. levél, amelyben arról ír, hogy beszédet tartott a senatus előtt, amelyben ő is megköszönte apja visszahívását, s e beszédnek a szövegét elküldi Praetextatusnak véleményezésre. Az 52. levelében pedig így fogalmaz: Orationem meam tibi esse conplacitam nihilo setius gaudeo, quam quod eam secunda existimatione pars melior humani generis senatus audivit. [...] securus examinis tui nihil moror sententias ceterorum. Quid si adfuisses, tam bonae voluntatis auditor? Ne ego digito, ut aiunt, supera convexa tetigissem. Praetextatus véleménye min-

\footnotetext{
${ }^{31}$ Ep. 1, 50, 1: Ego vero minimum animi angerer, si taceres, prae ut hoc est, quod mihi et patri unas atque eas oppido breves litteras detulisti. Ita tibi ambo digni singulis paginis non videmur? ${ }^{32}$ Ep. 1, 55, 1 .

33 Ep. 1, 44, 1. Az idősebb Symmachus önkéntes száműzetésének előzményeiről ld. Amm. Marc. 27, 3, 3-4, illetve lentebb az 50. jegyzetet. Vö. még Тóтн (2020: 182-184). 34 Symmachus egyik levelét (Ep. 1, 46) épp Titianus kézbesíti Praetextatusnak. 35 Ep. 1, 54.
} 
denki másénál fontosabb számára, és az minden bizonnyal készséggel volt segítségére és támogatta tanácsaival.

A barátságuk harmadik indoka lehetett a közös érdeklődés és a müvelt emberek társasága iránti igény. Utóbbi kifejeződésére több példát is találunk a levélgyüjteményben. $\mathrm{Az}$ egyik legjellegzetesebb az a Iamblikhoshoz írott rövidke episztola, amely a következőképpen kezdődik: Plerisque amor est undique gentium pretiosa conquirere. Me iuvat studiosos sapientiae viros in amicitiae possessionem vocare. ${ }^{36}$ Fentebb már utaltunk Praetextatus nagy műveltségére és főként a vallási kérdésekben való rendkívüli jártasságára, amelyet nemcsak felesége, de az utókor is dicsőített, és Symmachus leveleiből is az derül ki, hogy még a pihenésre szánt idejét is olvasással vagy írással töltötte, elébe helyezve a tudós elfoglaltságokat a könnyed szórakozásoknak. ${ }^{37}$

A két férfiú közötti szoros barátság nemcsak a levelek hangnemében és a baráti viszony gyakori említésében nyilvánul meg, hanem abban is, ahogyan Symmachus aggódik Praetextatus egészségéért. „Örömmel tölt el, hogy egészséged visszatért, mert mindig a te épséged az én legfőbb kívánságom" - kezdi a 45. levelet. Majd arra biztatja barátját, ha már jól megerősödött, írjon neki hosszabb leveleket. Másutt, amikor Paulina rossz egészségi állapota miatt aggodalmaskodik, akkor is valójában barátját félti, mivel tisztában van vele, milyen erős kötelék van a házastársak között, s úgy véli, felesége gondjai őt is megviselik. ${ }^{38}$

Az általuk viselt papi tisztségek szintén erős kapocsnak bizonyulnak. Praetextatushoz hasonlóan Symmachus ugyancsak pontifex volt már karrierje korai szakaszától, s e közös feladat témát szolgáltat több levél számára is. ${ }^{39} \mathrm{E}$ levelek alapján úgy látszik, Symmachus papi kötelességeit nagyon komolyan vette és igyekezett megfelelni minden elvárásnak a collegium pontificum tagjaként. Nincs tudomásunk róla, hogy más papi tisztséget betöltött volna, vagy valamilyen misztériumvallás beavatottja lett volna. Mindenesetre pontifex maiori feladatairól kilenc levelében esik szó a levélgyüjteményben, s ebből három címzettje

\footnotetext{
${ }^{36}$ Ep. 9, 2, 1.

${ }^{37} \mathrm{Vö.} \mathrm{Ep.} \mathrm{1,} \mathrm{47;} 53$.

${ }^{38}$ Ep. $1,48$.

${ }^{39}$ Ep. 1, 46; 49; 51. Bizonyos értelemben még a 47. levelet is ide lehetne sorolni.
} 
Praetextatus. Az általunk ismert többi forrás Praetextatust mint rendkívül vallásos embert mutatja be, aki példásan látta el feladatait a különböző papi testületekben. Ezért is érdekesek az említett levelek, amelyek látszólag teljesen más képet festenek róla. Symmachus tréfásan azért korholja, hogy miközben ő maga éjt nappallá téve keményen dolgozik a papi collegium feladatainak ellátásán, addig Praetextatus hol Baiaeban, hol Etruriában lógatja a lábát és teljességgel elhanyagolja papi teendőit. A 47. levélben például a következőket írja: Silentii nostri ratio diversa est, sed unus effectus. Me inpedit pontificalis officii cura, te Baiani otii neglegentia. Campania olyan csodálatos vidék, hogy még Hannibált is lefegyverezte, s ehhez foghatóval Odysseus sem találkozott kalandos hazatérése során, érthető hát, hogy Praetextatus is szívesen időzik arrafelé. Azonban Symmachus önző dolognak tartja barátja részéről, hogy miközben az a maga örömére olvas és írogat baiaei nyugalmában, megfeledkezik baráti kötelességéről, vagyis arról, hogy levelet küldjön neki. Tehát itt igazából nem Praetextatus távolléte, vagy úgymond semmittevése bosszantja, hanem az, hogy elhanyagolja őt, a barátját. A másik, hasonló témájú levél azonban már sokkal komolyabb. Az 51. levélben arról számol be, hogy bár vidéken tartózkodott, de a városban uralkodó ingatag viszonyok visszatérésre kényszerítették, s annak ellenére tér vissza, hogy ezzel saját biztonságát veszélyezteti. Mivel a levelek datálása sokszor bizonytalan, nem tudjuk pontosan, mi az a malum commune, amire utal. Callu 383-ra teszi a levél keletkezését, és Gratianus meggyilkolásával, illetve az ugyanebben az időben fellépő éhínséggel hozza összefüggésbe: nagy valószínüséggel valóban ezekkel kapcsolatos dolgok állhattak a sürgős visszatérés hátterében. ${ }^{40}$ Bármire is vonatkozzék azonban Symmachus allúziója, a levél alapvetően ismét az általa ellátott papi feladatkörről szól. Kifejti ugyanis, hogy azért is kellett visszajönnie Rómába, mivel ő következik soron az egyhónapos papi teendők ellátásában. Ez egy igen fontos információ a késő antikvitásban müködő papi testületek struktúrájára és kötelezettségeire vonatkozóan. Arra céloz ugyanis, hogy a pontifexek felosztották egymás között a rituálé diktálta feladatokat, mégpedig úgy, hogy minden hónapban mások voltak beosztva szolgálatra. Ez a rendszer valószínüleg a 3. század végén alakult

\footnotetext{
40 A kérdésről bővebben ld. az Ep. 1, 51-hez tartozó 85. jegyzetet.
} 
ki és Symmachus idejében is érvényben volt. Egy másik érdekes megjegyzése, hogy nem akarja egyik kollégáját sem megkérni, hogy helyettesítse őt, mivel oly nagy nemtörődömséget tapasztal társai körében. Fuerit haec olim simplex divinae rei delegatio: nunc aris deesse Romanos genus est ambiendi1 - panaszkodik a szerző, mondatával talán a papság és általában a hagyományos római vallást tartó polgárok létszámbeli fogyatkozására utalva, illetve az egyre erőteljesebb krisztianizálódásra, mivel az immáron keresztény császárok alatt viselt pogány papi tisztség hátráltathatta az ambiciózus arisztokraták hivatali előmenetelét. A helyzet tehát nem kedvező, s úgy látszik, kevesen vannak az olyan lelkiismeretes pontifexek, mint Symmachus. Ezért érthetjük meg, miért kérdezi szorongva Praetextatustól, hogy ugyan meddig marad még Etruriában. Mert Praetextatus éppen most sincs jelen, hanem etruriai birtokain időzik, s Symmachus nem tudja elképzelni, mi lehet az, ami fontosabb számára jelenleg polgártársai gondjainál. Mindezek alapján azt hihetnénk, hogy tulajdonképpen Praetextatus is azon római előkelők közé tartozik, akik csak a titulus kedvéért vállalnak részt a különböző papi testületekben és valójában nem törődnek az ezzel járó kötelességekkel, vagy hanyagul látják el azokat. Symmachus azonban minden bizonnyal nem így vélekedett róla, épp ezért fordult hozzá segélykérőn.

A harmadik, papi feladatokkal kapcsolatos levél ugyancsak egy bizonyos szorongató helyzethez kapcsolódik, és úgy látszik, Praetextatus az iránt érdeklődött, hogyan sikerült megoldani a problémát. Itt sem ismerjük a pontos időpontot, csak a helyszínt: Spoletiumban valamiféle csodajelet észleltek, s emiatt engesztelést kellett tartani. Az engesztelő áldozatot Iuppiternek és az állam jólétéért felelős Fortuna Publicának mutatták be, azonban hiába kedveskedtek többször is állatáldozattal az említett isteneknek, nem sikerült elhárítani a bajt. Ezért az a döntés született, hogy összehívják a testület többi tagját, hogy közösen döntsenek arról, hogyan tovább. Ez alkalommal az szóba sem kerül, hogy esetleg Praetextatusnak is részt kellene vennie ezen a gyülésen, Symmachus mindössze annyit mond neki, hogy majd tájékoztatja a további fejleményekről. Ez a 49. levél elsősorban azért tarthat érdeklődésünkre számot, mert egyértelmüen bizonyítja, hogy jóllehet ekkorra már számos tör-

${ }^{41}$ Ep. 1, 51. 
vényt hoztak a nyilvános áldozatbemutatások ellen (a legkorábbi 341-re datálható közülük), azok mégis szívósan továbbéltek Itália-szerte. Egyébként, hogy Symmachus mekkora jelentőséget tulajdonít az ősi vallási hagyományok megőrzésének, nemcsak az előbbi levelek igazolják, hanem többek között a 9. könyv azon két levele is, ${ }^{42}$ amelyekben nagyon határozottan és ellentmondást nem türően követeli a régi szokások szerinti legszigorúbb büntetést egy, a tisztaságát elveszítő Primigenia nevü Vesta-szűzre és annak Maximus nevű szeretőjére.

Ha mérlegre tennénk Praetextatus jó és rossz tulajdonságait az alapján, hogy Symmachus levelei hogyan láttatják őt, a két serpenyő közel egyensúlyba kerülne. Praetextatus müvelt barát, aki tanácsot ad, véleményez, együtt örül és együtt gyászol Symmachusszal, ugyanakkor hanyag barát is, aki nem ír, vagy nem elégszer és nem eleget, aki nem törődik eléggé papi hivatalával, és a gondokkal teli időkben a közügyekben való aktív részvétel helyett a vidéki nyugalmat és pihenést választja. A Praetextatusszal szemben megfogalmazott kritikákat, vagy inkább csipkelődéseket Symmachus rendszerint humoros formában adja elő. Az, hogy ezt gond nélkül megteheti a nála jóval idősebb és nagy tisztelettel övezett arisztokratával, arra utal, hogy Praetextatus fogékony volt a tréfáira és nem sértődött meg miattuk. Valószínűleg maga is jó humorérzékkel rendelkezett, nem véletlenül születhetett az az anekdota, amely szerint Damasus pápával viccelődve azt mondogatta: „Tegyetek meg Róma püspökévé, s nyomban keresztény leszek." ${ }^{43}$

Ugyancsak egyfajta ambivalencia mutatkozik meg a halála után Praetextatusnak állítandó szobor kérdése kapcsán. Praetextatus 384 decemberében bekövetkezett halálát ${ }^{44}$ követően a Vesta-szüzek főpapnője, Coelia Concordia szobrot akar állíttatni az elhunytnak, amely ellen Symmachus hevesen tiltakozik. ${ }^{45}$ Indokai részben érthetőek, amelyekben

42 147. és 148. levelek.

${ }^{43}$ Hieronymus, Contra Ioannem Hierosolymitanum, 8: Facite me Romanae urbis episcopum, et ero protinus Christianus.

${ }^{44}$ Praetextatus halálának hírére az egész város felbolydult (Hier. Ep. 23). Symmachus szerint az emberek még a szokásos színházi szórakozásaikkal is felhagytak egy időre, olyan nagy volt a gyászuk (Rel. 10, 2).

${ }^{45}$ Ep. 2, 36, 2: Praetextato nostro monumentum statuae dicare destinant virgines sacri Vestalis antistites. Consulti pontifices, priusquam reverentiam sublimis sacerdotii, aut longae aetatis 
egyfelöl ismét a hagyományokat a legteljesebb mértékben tiszteletben tartó pontifex mutatkozik meg, aki úgy véli, nem helyénvaló, ha a Vestalisok egy férfinak emeltetnek szobrot (még akkor sem, ha az a férfi Vesta papja volt), másrészt az óvatos politikus és a régi vallás ügyét féltő senator, aki az aktuális helyzetet nem tartja alkalmasnak egy ilyen gesztus megvalósításához, ráadásul az előzmény nélküli példát később méltatlan személyekre is alkalmazhatnák. Véleményével kevesen értettek egyet, többek között Praetextatus felesége, Paulina sem támogatta őt, így végül elkészült és felállításra került a szobor, valószínüleg a Vestaszüzek házában. Paulina pedig hálából Coelia Concordiának állíttatott szobrot Esquilinus dombi otthonának atriumában, amely szobornak a talapzata ma is megvan. ${ }^{46}$

Miközben a tradícióra és a nem megfelelő helyzetre hivatkozva Symmachus elgáncsolná a Vestalis Maxima szoborállítási tervét, ugyanabban az időben praefectus urbiként ő maga kéri 12 . relatiójában ${ }^{47}$ Theo-

usum, vel conditionem temporis praesentis expenderent; absque paucis, qui me secuti sunt, ut ejus officium statuerent, annuerunt. Ego, qui adverterem, neque honestati virginum talia in viros obsequia convenire, neque more fieri, quod Numa auctor, Metellus conservator religionum, omnesque pontifices maximi nunquam ante meruerunt: haec quidem silui, ne sacrorum aemulis enuntiata noxam crearent, inusitatum censentibus. Exemplum modo vitandum esse rescripsi, ne res justo orta principio, brevi ad indignos, per ambitum deveniret.

${ }^{46}$ CIL VI 2145. Bár Paulina és Coelia Concordia a szoborállítás ügyében diadalmaskodtak Symmachusszal szemben, SALZMANN meglátása szerint mégis az utóbbi tudott hosszú távú sikert elérni annak a képnek a kialakításával, amelyet a levelek mutatnak nekünk: „,...] his humanizing image of Praetextatus as a witty but somewhat delinquent pagan undermindes attempts at representing this eminent senator as a virtual 'holy man'. Rather, Praetextatus is portrayed [...] as a powerful member of Symmachus's circle of friends, willing to share in public duties associated with the state cults but more eager to share literary witticisms than to come to meetings of the pontifical college." SALZMANN (2011: 95-96).

47 Rel. 12, 1-2: Licet Vettius Praetextatus naturae lege resolutus sit, vivit tamen in memoria et amore cunctorum felicior civium lacrimis quam quisquam gaudiis suis, atque hoc uno punit invidiam, quod tantum ei mors ad gloriam contulit, ut huic quoque fortunae livor debeat invidere, domini imperatores Valentiniane Theodosi et Arcadi inclyti victores ac triumphatores semper Auggg. Nam praeter illum populi Romani inusitatum dolorem etiam senatus inpatiens dispendii sui solacium petit de honore virtutis vestrumque numen precatur, ut virum nostra aetate mirabilem statuarum diuturnitas tradat oculis posterorum [...] quia ornamentis bonorum incitatur imitatio et virtus aemula alitur exemplo honoris alieni. 
dosiustól és Arcadiustól, hogy halhatatlan érdemeire való tekintettel állítsanak köztéri szobrot Praetextatusnak. Hosszasan magasztalja elhunyt barátja kiváló erényeit, hangsúlyozva, hogy nem azért kéri a szoborállítást, mintha Vettius valaha is világi jutalom után vágyódott volna, hanem hogy e csodálatra méltó férfiú emléke példa gyanánt fennmaradjon az utókor számára. Barátja és „harcostársa” elvesztése annyira megviseli, hogy úgy dönt: ideje lejárta elött lemond a praefectus urbi hivataláról. ${ }^{48}$

${ }^{48}$ Rel. 10, 1-3: Praetextatus vester, Praetextatus bonorum, antiquae probitatis adsertor, invida sorte subtractus est [...] Et ille quidem functus est lege naturae, nos vero socios animi sui vestrique iudicii tanto dolore confudit, ut otii remedium postulemus. Sileo cetera, quae me non sinunt praefecturam ferre patienter: vel haec una consortis amissio iusta est ad impetrandam vacationem. Ament alii perpetuas potestates [...]. 


\title{
SYMMACHUS PRAETEXTATUSHOZ ÍROTT LEVELEI ${ }^{49}$
}

\author{
1,44 . \\ Symmachus Agorius Praetextatushoz
}

376

1. Az irántam való figyelmességed megérdemli, hogy ne tartsam előtted titokban azokat a dolgokat, amelyek legutóbb dicsőségemre váltak. Úgy hiszem, a Fáma már tudatta veled, hogy a senatus többszöri szavazással, s végül - szokatlan megtiszteltetésként - követek küldésével visszahívta atyámat, aki vidéki elvonultságában próbálta megemészteni azt az igazságtalanságot, amely háza elvesztése miatt érte. ${ }^{50}$ Ezért az első napon,

${ }^{49}$ A fordítás alapjául CALLU (2003) szövegkiadása szolgált. A jegyzetek CALLU (2003) és SALZMANN (2011) jegyzeteinek figyelembevételével készültek.

${ }^{50}$ A szónok apja, Lucius Aurelius Avianius Symmachus a praefectus urbi tisztségét töltötte be 364-365 között. Ammianus Marcellinus tudósítása szerint (Amm. Marc. 27, 3, 3-4) hivatalát mindenki megelégedésére, kiválóan látta el. Két évvel később azonban egy plebeius megvádolta öt azzal, hogy praefectusként azt mondta: inkább meszet olt a borával, mint hogy olyan áron adja el, amilyet tôle remélnek ([...] libenter se vino proprio calcarias extincturum, quam id venditurum pretiis, quibus sperabatur). Az állítólagos kijelentésen felháborodott tömeg felgyújtotta római villáját, amely a mai Trastevere negyedben állt. Az esetet követően Symmachus vidékre távozott mintegy önkéntes számüzetésbe, s évekig nem tért vissza Rómába. Fiával folytatott levelezéséből (Symm. Ep. 1, 2) és az ifjabb Symmachus egyik beszédéből $(O r .5,1)$ is tudjuk, hogy elvonultságának idején leginkább az irodalomban, a versírásban és az olvasásban lelte kedvét. Annak, hogy az egykori praefectus urbi vonakodott a városba visszatérni, és a senatusnak végül követséget kellett küldenie hozzá, valószínúleg az lehetett az oka, hogy nem minden senator támogatta a visszahívását, ő pedig nem akart viszályt szítani a rend tagjai között. Legalábbis erre enged következtetni az az utalás, amelyet fia tesz a már említett beszédében $(O r .5,1)$ : Cesserat quidem sponte ille per verecundiam paucorum facilitati $[. .$.$] - ahol a facilitas 'gyarlóság', 'felelőtlenség' jelentésben értendő. Végül$ azonban helyreállt a harmónia, amit az is igazol, hogy Avianius Symmachust consulnak jelölték a 377. évre. Ez egyúttal azt is jelezte, hogy az új császár, Gratianus jó viszony kialakítására törekedett a senatusszal, ugyanis ebben az időszakban nagyon ritkán fordult elő az, hogy a senatorok közül válasszanak consult. A dolog rendkívüli jelentőségét az is mutatja, hogy az ifjabb Symmachus is köszönetet mondott a kegyért egy beszédben (Or. 4), amely valószínűleg 376 nyarán hangozhatott el. E kivételes lehetőség azonban végül mégsem tudta beváltani a hozzá füzött reményeket, mert Symmachus valamikor az év második felében meghalt, még azelőtt, hogy hivatalát betölthette volna. (A sors iróniája, hogy Praetextatusszal 
amint lehetősége adódott a beszédre a többi tag jelenlétében, atyám azzal a méltóságteljes ékesszólással mondott köszönetet a senatusnak, amely ismertté tette őt. Elseje volt akkor, az év kezdőnapja. ${ }^{51}$

2. Kis idő múlva, mivel megígértem, hogy segítek egy beszéddel Trygetius ${ }^{52}$ barátom fiának, aki a praetori hivatalra pályázik, a lelkiismeretem arra sarkallt, hogy a magam számára kijelölt kötelezettség apropóján felvállaljam azt a szolgálatot is, amellyel atyámnak tartoztam, bár - mint említettem - ő azt már megfizette a senatusnak. Tehát január 9-én a legtekintélyesebb rend körében beszéltem,53 mihelyt kézbe veszed majd ezt a beszédet, kitalálod magad a többiek véleményét. ${ }^{54}$ Mivel bizonytalan vagyok az értékelésedben, ${ }^{55}$ úgy gondoltam, titokban kell tartanom mások vélekedését, nehogy úgy tünjek fel, mint aki nyomást gyakorol rád az oly tiszteletre méltó rend korábbi ítéletével. Ég veled!

is ugyanez történt: a következő évre kijelölt consulként 384 decemberében meghalt.) Ezt követően már nem egy másik senatort állítottak a helyére, hanem Merobaudes mellett maga Gratianus lett a másik consul. Vö. KELLY (2013: 357-409, főként: 393).

51 376. január elsejéről van szó.

${ }^{52}$ Máshonnan nem ismert személy. Vö. Trygetius 1, PLRE I. 923.

53 Symmachus valóban mondott egy beszédet Trygetius fia praetorrá választása érdekében (Or. 5, Pro Trygetio), amelyből azonban csak egy rövid, öt paragrafusnyi töredék maradt fenn. Ebből az első háromban apja, Avianius Symmachus - az 50. jegyzetben részletezett visszahívása miatt méltatja a senatust és az uralkodót, s csak ezután tér át Trygetius fiának ügyére: Demus aliquid operae, aliquid temporis etiam Trygetio clarissimo et emendato viro qui vos oratos per me adque exoratos cupit, ut eius filium functioni praetoriae destinatum decimus annus accipiat. Si voluntas spectanda est, debetis munificum senatorem probare; si facultates, nihil plus potestis inponere. Me quoque in hoc negotio cogitari decet, qui soleo agere gratias, qui obliterari benefacta non patior. Recte locantur officia secunda, ubi prima viguerunt. Istum novo debito alligate, me gemino [...] (Or. 5, 4-5). A szövegrész alapján úgy látszik, hogy az akkoriban igen tekintélyes vagyont igénylő praetori hivatal betöltése tíz év múlva lenne esedékes, továbbá feltételezhetjük, hogy Trygetiusnak volt valamiféle szerepe Symmachus apjának visszahívásában, ezért érezhette úgy a szónok, hogy tartozik neki.

${ }^{54}$ Egy későbbi levélből $(E p .1,52)$ megtudjuk, hogy a pars melior humani generis kifejezéssel illetett senatus kedvezően fogadta Symmachus beszédét, amelyet egyébként Praetextatuson kívül több más ismerősének is elküldött véleményezésre: valószínűleg ugyanerről a beszédről van szó a Hesperiusnak (Ep. 1, 78) és Syagriusnak (Ep. 1, 96; 105), továbbá a Rusticus Iulianusnak (Ep. 3, 7) és a Neoteriusnak $(E p .5,43)$ írt levelekben is.

55 Bár Praetextatus válasza nem ismert, minden bizonnyal dicsérően nyilatkozhatott a beszédről, amivel - az Ep. 1, 52 tanúsága szerint - rendkívül nagy örömet okozott a saját maga szerint is "dicséretre éhes” (laudis avarus, Ep. 1, 78, 1) Symmachusnak. 


\section{1,45 . \\ Symmachus Agorius Praetextatushoz \\ 385 elöt $t^{56}$}

1. Örömmel tölt el, hogy egészséged visszatért, mert mindig a te épséged az én legfőbb kívánságom. Most, ha az istenek akaratával helyreállt erőd kedélyed elevenségét is megújította, tegyél róla, hogy leveleid sok oldallal gyarapodjanak. Gyülölöm, ha valaki takarékosan bánik a jó szóval, tudniillik az írás rövidsége közelebb áll a semmibevevéshez, mint az udvariassághoz. Nem olyan levelet akarok, amelyet éppen csak az ajkad széléről csepegtetsz, olyat kérek, amely nem tud kiapadni, amely szíved legbenső forrásából fakad. ${ }^{57}$

2. Emlékszem, egykor dicséretre vált a spártai rövidség, én azonban a római szabályok szerint beszélek veled, vagy ha úgy akarod, az attikaiak szerint, ahol a szóbőségből annyi ékesség származott, hogy számomra úgy látszik, a spártaiak az összehasonlítástól való félelmükben fordították más irányba törekvéseiket. ${ }^{58}$ Többet is akarnék mondani, azonban a saját módszeredet követve kell ösztökélnem téged. Egyszersmind vigyáznom kell, nehogy megsértselek a sok beszéddel. Tehát saját szokásommal felhagyok, míg a tiednek alávetem magam. Ebből megérted, hogy igen rossz helyzetbe kerültél, mert ha nem írsz nekem hosszú válaszlevelet, az olyan lesz, mintha azt szeretnéd, hogy én is keveset írjak neked. Ég veled!

\footnotetext{
${ }^{56}$ A levélben nem szerepel semmiféle olyan információ, amely elősegítené a pontosabb datálását, így csak abból indulhatunk ki, hogy Praetextatus 384 decemberében halt meg, tehát a levélnek ez előtt kellett íródnia.

57 Symmachus gyakran panaszkodik levelezőpartnereinek arra, hogy nem írnak neki, vagy csak igen rövid üzeneteket küldenek. Ez részben tekinthető egy, a levelezésekre jellemző bevett formulának, de a bensőséges barátság kifejeződésének is.

58 Macrobius négyféle beszédstílust különböztet meg (Sat. 5, 1, 7), amelyek közül a spártaiakra is jellemző tömör előadásmód legjelesebb képviselője Rómában Sallustius volt, míg a gazdag és választékos stílus leginkább Plinius és Symmachus írásaiban mutatkozott meg: Quattuor sunt [...] genera dicendi: copiosum in quo Cicero dominatur, breve quo Sallustius regnat, siccum quod Frontoni ascribitur, pingue et floridum in quo Plinius Secundus quondam et nunc nullo veterum minor noster Symmachus luxuriatur.
} 
1,46 .

Symmachus Agorius Praetextatushoz

$360 / 365-380^{59}$

1. Megspórolhattam volna magamnak az írást, mivel úgy látszik, testvérem $^{60}$ szavaival bőségesebben eleget tesz majd neked, mint az én levelemmel, ám a tisztes kötelességteljesítés nagyobb haszonnal kell járjon, mint a néma semmittevés. Tehát annak érdekében, hogy barátságunk becsben tartása javamra váljon, nem kell csendben lennem, de nem is kell mindent levélre bíznom, hogy neki is maradjon valami, amit elmesélhet. Tudd meg azonban a probléma fő pontjait, s azon ügyek lényegét, amelyekben testvérem tájékozott, s bővebben kifejti majd őket, ha kérdezed.

2. A papi testület tagjai között megegyezés született arról, hogy bízzuk az istenekről való gondoskodást állami szolgálatként a polgárok felügyeletére. ${ }^{61}$ Ugyanis elvész az istenek jóindulata, ha nem tartják fenn a kultusz révén. Ezért a szokásosnál sokkal nagyobb tiszteletadást tartottak az égieknek. Úgy látom, arra vársz, hogy elmondjak neked mindent, ami történt. Az én Titianusom jelentést tesz majd neked, mivel rá-

59 E levél keletkezése idején Symmachus már pontifex maior volt. A Codex Theodosianus egyik feljegyzéséből $(8,5,25)$ tudjuk, hogy 365-ben a corrector Lucaniae et Brittiorum hivatalát látta el, míg egy, a fiától, Memmiustól származó dedikáció (CIL VI 1699) szerint e pozíciót időben megelőzte a quaestori, praetori és pontifexi tisztség elnyerése. Az ismereteink szerint valamikor 340 és 345 között született Symmachus mindezeket a hivatalokat életkoránál fogva 360 előtt nem viselhette, vagyis ez utóbbi év lehet a levél keletkezésének terminus post quemje. A levélvivő Titianus (róla bővebben a következő jegyzetben) 380-ban halt meg, így ez adja a datálás felső határát.

${ }^{60}$ Celsinus Titianusról van szó, aki valószínűleg fiatalabb volt Symmachusnál. Anyai nagyapja, Fabius Titianus (cos. 337) és apai nagybátyja, Aurelius Celsinus (praefectus urbi 341-ben és 351-ben) után kapta a nevét. Symmachus levélgyüjteményében tizenhárom olyan levél maradt fenn, amelyeknek Titianus a címzettje (Ep. 1, 62-74). Ezek többsége 380-ban íródott, amikor Titianus töltötte be a vicarius Africae pozícióját. Az egyik levélből (Ep. 1, 68) megtudjuk, hogy két papi testületnek is tagja volt, de hogy pontosan melyeknek, az nem derül ki. SEECK (1883: cvi) azt valószínúsítette, hogy a pontifex Vestae és a pontifex Solis tisztségekről lehet szó, ami nagyon is elképzelhető, azonban ezt tényszerüen bizonyítani eddig még nem sikerült.

${ }^{61}$ Nem tudjuk, hogy Symmachus ezzel a mondatával pontosan milyen kultikus tevékenységre utal, és hogy mi válthatta ki e közelebbről nem meghatározható szertartás átadását a népnek. Mindenesetre az figyelemre méltó, hogy a régi római vallás papjai a 4. század második felében még aktívan gyakorolják szakrális tevékenységeiket. 
bíztam, hogy mesélje el részletesen, amit hallani szeretnél. Ha még nem ismered a császárok ediktumát, ${ }^{62}$ ugyanő elmondja majd neked a tartalmát. A szobraitokat már visszakaptátok a nép szinte ugyanolyan tetszésnyilvánításai közepette, mint ahogyan elveszítettétek őket. ${ }^{63}$ Nevess, ha tetszik. Távol voltál, úgyhogy nevethetsz. Nem mondok többet, nehogy - miután a jó hírekről csak röviden szóltam - úgy tünjek fel, mint aki a keserűségek felett időzik. Ég veled!

$$
\begin{gathered}
1,47 . \\
\text { Symmachus Agorius Praetextatushoz } \\
\text { 360/365-385 elót } \text { t }^{64}
\end{gathered}
$$

1. Hallgatásunk oka különböző, de eredménye ugyanaz. Engem a főpapi kötelezettség ${ }^{65}$ gondja, téged a baiaei pihenés gondtalansága hátráltat. Ugyanis nem kevésbé teszi restté az embert a levélírásra a lelki nyugalom, mint az elfoglaltság. Nem csoda, ha egészen magának követel téged az a partvidék, hiszen megbízható információnk van arról, hogy még a háborúban győzhetetlen Hannibál is megadta magát Campaniá-

62 Csak találgatások vannak azt illetően, mely császári ediktumra gondolhat itt Symmachus. KoHNS úgy véli, hogy arról a 380-as rendeletről (Cod. Theod. 16, 1, 2) lehet szó, amely államvallássá nyilvánítja a kereszténységet, ld. KOHNS (1961: 157). CALLU szerint a rendelet visszaszolgáltatta a templomoktól korábban elkobzott javakat, ld. CALLU (2003: 224, 4. jz), s így a következő mondatban említett szobrok visszaadása is ezzel áll összefüggésben. Felmerült egy 376-os rendelkezés (Cod. Theod. 15, 1, 19) lehetősége is, amely megtiltja új építkezések kezdeményezését Rómában és előírja a régi épületek megóvását, helyreállítását. Ez utóbbihoz kapcsolódna a szobrok visszaszolgáltatása, ld. LIZZI TESTA (2004: 373-374).

63 SEECK (1883: lxxxviii-ix) úgy gondolja, ez a mondat nem áll kapcsolatban az előzőben említett császári rendelettel, és valójában Praetextatus azon tiszteleti szobraira utal, amelyeket még életében állítottak neki, azonban miután magára vonta a nép haragját, a ledöntés veszélye fenyegette őket. Ezt a magyarázatot bár teljességgel elvetni nem lehet, ugyanakkor nem is tünik túl meggyőzőnek. Nagyobb a valószínüsége, hogy a szentélyekből vagy közterekről korábban vallási okokból eltávolított szobrokról lehet szó.

${ }^{64}$ A levél datálására vonatkozóan ld. az 56. és 59. jegyzeteket. CALLU (2003: 110) 383-ra keltezi és összekapcsolja az 51. levéllel (ld. lentebb), azonban - miként azt már SALZMANN (2011: 104, 1. jz) is jelezte - ez azért valószínútlen, mert az utóbbi levél arról tudósít, hogy Praetextatus Etruriában tartózkodik, míg a jelenlegi szerint épp Baiaeban van.

65 Symmachus mint pontifex maior valószínúleg már viszonylag fiatalon a pontifexek collegiumának tagja lett. 
nak. ${ }^{66}$ Éghajlatának és fekvésének csábításával nem ér fel sem a jövevényeket csapdába ejtő lótuszfa, sem Circe bájitalai, sem a félig madártestü leányok triásza. ${ }^{67}$ 2. Nem állítom, hogy kényelemben töltöd szabadnapjaidat, s azt sem gondolom, hogy az érzéki örömök miatt erényed hanyatlani kezdett. Azonban míg magadnak olvasol, magadnak írsz, s a városi ügyektől megfáradva elvonultsággal enyhíted nagyszerü szellemedet, a barátság egyetlen kötelezettségét sem teljesíted. Miért nem ragadsz íróveszőt, s viszonzod egy válasszal az irántad való szeretetemet? Kivéve, ha nem akarod inkább a pontifex tekintélyét megtapasztalni. Sok dologról kell döntenünk a collegiumban. ${ }^{68} \mathrm{Ki}$ adott neked szabadságot a közfeladatok alól? Meglátod majd, papként milyen ítéletet hozok, ha nem teszel eleget a barátság törvényének. Ég veled!

\footnotetext{
${ }^{66}$ Vö. Val. Max. 9, 1, ext. 1: At Campana luxuria perquam utilis nostrae civitati fuit: invictum enim armis Hannibalem inlecebris suis conplexa vincendum Romano militi tradidit. Illa vigilantissimum ducem, illa exercitum acerrimum dapibus largis, abundanti vino, unguentorum fragrantia, veneris usu lasciviore ad somnum et delicias evocavit. Ac tum demum fracta et contusa Punica feritas est, cum Seplasia ei <et> Albana castra esse coeperunt. Quid iis ergo vitiis foedius, quid etiam damnosius, quibus virtus atteritur, victoriae relanguescunt, sopita gloria in infamiam convertitur animique pariter et corporis vires expugnantur, adeo ut nescias ab hostibusne <an> ab illis capi perniciosius habendum sit?

${ }^{67}$ Utalás azokra a csábításokra, amelyekkel Odysseusnak kellett szembenéznie Trójából való hazatérése során: Hom. Od. 9, 82-97 (lótuszevők); 10, 210-240 (Circe); 12, 39-54; 165-200 (Szirének). Az eredeti mondatban olvasható hapaxok: retinax, tricinium, semivolucrum Campania különlegességét hivatottak hangsúlyozni.

${ }^{68}$ A collegium pontificum a római államvallás legmagasabb rangú papjainak szervezete volt a pontifex maximus irányítása alatt. Utóbbi hivatalt Augustustól kezdve a mindenkori császár töltötte be. Eredetileg az áldozatbemutatásokat felügyelték, később azonban tevékenységük számos feladatkörrel bővült, mint pl. tanácsadás szakrális kérdésekben, a főpapi jog értelmezése, bizonyos rituálék vezetése stb.
} 


\section{$1,48$. \\ Symmachus Agorius Praetextatushoz \\ 385 elött69 $^{69}$}

Jóságos istenek! Mennyire bizonytalan és kifürkészhetetlen minden az ember számára! Bizonyára azért vonultál el Baiaeba, hogy lelkednek enyhülést találj. Miféle gonosz szem ${ }^{70}$ rontotta meg célul kitüzött pihenésed? Tehát Paulina, aggodalmunk közös tárgya életének végső fázisába ért. Vagy annyira félted, hogy minden ôt ért kellemetlenséget veszedelmesnek tartasz? ${ }^{71}$ Bármelyik is az igaz, el lehet képzelni, milyen viszontagságokat élsz meg nappal, s mennyit virrasztasz éjszaka. Úgy születtünk, hogy gyakran kelljen csapásokat kiállnunk. Az örömök elmúlnak, s minden jó dolog oly rövid ideig tart, hogy érezni is alig lehet. Azonban hagyjuk e dolgok megvitatását a filozófusokra, mi pedig vegyük most már rá magunkat, hogy derüsebb legyen a kedvünk, mivel az istenek békéje ${ }^{72}$ Paulinánk egészségét tartósan helyreállította. Ég veled!

${ }^{69}$ A datálásra vonatkozóan ld. az 56. jegyzetet.

70 Symmachus itt a szemmel verésre utal. Az a széles körben elterjedt hiedelem, miszerint egyesek pusztán a tekintetük erejével képesek szerencsétlenséget hozni azokra, akikre ránéznek, szinte egyidős az emberiséggel és a mai napig is számos nép hagyományaiban megtalálható. A rómaiak körében is jól ismert babonára vonatkozóan vö. Verg. Ecl. 3, 103; Plin. HN 7, 2, 16.

${ }^{71}$ A szövegkontextus alapján valószínűsíthető, hogy ez a levél az előzővel áll kapcsolatban: Symmachus korholó üzenetére válaszként Praetextatus tájékoztathatta őt felesége betegségéről és emiatti aggodalmairól, ezzel indokolva levélírási kötelezettségének elmulasztását. A mélyen együttérző barát sorai is arra engednek következtetni, hogy Praetextatus és felesége között nagyon szoros volt a kötelék. Kuriózumnak számít, hogy Symmachus nevén nevezi Paulinát: ezt még a feleségével vagy a lányával sem teszi meg. Általában véve is nagyon ritkán beszél nőkről a leveleiben, hogy Paulinával mégis kivételt tesz, az lehet a tiszteletének jele, de arra is rámutathat, mennyire befolyásos asszony volt Praetextatus felesége.

72 Symmachus itt egy, a valláshoz kötődő terminus technicust, a pax deorum kifejezést használja, amely az istenek és emberek közötti harmonikus egyensúlyt jelenti. A betegség e harmónia megbomlásának jele. 
1,49 .

\section{Symmachus Agorius Praetextatushoz 360/365-385 előtt ${ }^{73}$}

A köz javára született polgárként ${ }^{74}$ azt kérdezed, hogy e nyugtalanító helyzetet ${ }^{75}$ illetően mely hírek állnak legközelebb az igazsághoz. Biztos forrásokból kedvező dolgokat tudtunk meg, azonban ezután a hosszas hallgatás miatti gyanú izgatott híreszteléseknek adott helyet. Én azonban semmit sem törődöm az olyan vélekedésekkel, amelyekről nem lehet tudni, kitől származnak. Lelkemben nagy a szorongás, mert a számos áldozatbemutatás, amelyeket minden egyes hivatali személy többször is megismételt, még nem engesztelte ki a köz nevében a spoletiu$\mathrm{mi}^{76}$ csodajelet. ${ }^{77}$ Ugyanis Iuppitert alig békítette meg a nyolcadik áldo-

${ }^{73}$ A datálásra vonatkozóan $1 d$. az 56. és 59. jegyzeteket.

${ }^{74}$ civis ad bonum commune genitus - Hasonló kifejezéssel más leveleiben is találkozunk: Ep. 3, 43; 3, 55. CALLU (2003: 225, 5. jz) a hivatalos terminológia hatását látja benne, $\mathrm{s}$ Constantinus 308-as, Lyonban vert pénzérméinek feliratát hozza fel párhuzamként: Principi iuvent(utis) b(ono) r(ei) p(ublicae) n(ato), vö. RIC VI Lugdunum 270, 271, 286, 298 - online megtekinthetők: OCRE adatbázis, http://numismatics.org/ocre/ - Utolsó megtekintés: 2021. 09. 07.

${ }^{75}$ Nem tudjuk, milyen nyugtalanító helyzetre gondolhatott Symmachus. SEECK (1883: lxxxix) a 378. augusztus 9-ei katasztrofális hadrianopolisi csatavesztéssel hozza összefüggésbe a mondatot, ezt azonban valójában semmi nem támasztja alá a levélben. Erre alapozva ő és CALLU (2003: 111) is a levelet 378 körülre datálja.

${ }^{76}$ Spoletium (ma Spoleto) umbriai város Rómától 120 km-re észak-keleti irányban a Via Flaminia mentén.

77 A rómaiak hite szerint, ha az emberek valamely helytelen cselekedetükkel magukra vonták isteneik haragját, azok nemtetszésüket különböző jelekkel (omen, ostentum, portentum, prodigium) fejezték ki. Ilyen figyelmeztető jelek lehettek a természeti csapások, a megmagyarázhatatlan, csodás jelenségek, a háborús vereségek vagy éppen a járványok. Mindezek arra utaltak, hogy az istenek elfordultak tőlük, megrendült a halandók és halhatatlanok közötti béke, a pax deorum (vö. 72. jegyzet). Ebben az esetben az istenek kiengesztelése, jóindulatuk újbóli elnyerése céljából különböző nyilvános szertartásokat végeztek, amelyek lebonyolításáért a pontifexek voltak a felelósek. Nem tudjuk, hogy Spoletiumban konkrétan milyen csodajelet észleltek, de mindazok az erőfeszítések, amelyeket Symmachus szerint az engesztelés és bajelhárítás érdekében tettek, azt jelzik, hogy valami nagy horderejű dologról lehetett szó. 
zati állat leölése, Fortuna Publicát ${ }^{78}$ pedig már tizenegyedszer tisztelték meg sokféle áldozati állattal sikertelenül. ${ }^{79}$ Tudod, hogy hol vagyunk. Most azt határoztuk, hogy gyülésre hívjuk a testület tagjait. Tudatom

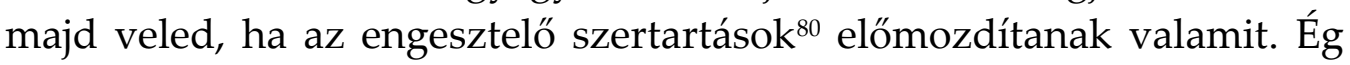
veled!

\section{$1,50$. \\ Symmachus Agorius Praetextatushoz 377 előtt ${ }^{81}$}

1. Én bizony, biztos lévén barátságodban, nem veszem rossz néven, bármi bünt követsz is el ellenem, mivel tudom, hogy szeretsz engem, azonban kötelességed elhanyagolása nem illik erkölcseidhez, amelyekből, azt kívánom, ne hiányozzék semmi dicséretre méltó. Azt gondolod, azért panaszkodom, mert semmit sem írsz, s arra készülsz, hogy megcáfold e hazugságot, mivel emlékszel rá, hogy írtál nekem valamit. Én azonban a legkevésbé sem haragudnék, ha hallgatnál, ahhoz képest,

\footnotetext{
${ }^{78}$ Fortuna Publica a szerencse és a sors istennőjének egyik aspektusa, a nép szerencséjének biztosítója (párhuzamba állítható az egyén szerencséjét garantáló Fortuna Privatával). Fortuna Publica Populi Romani a Kr. e. 3. század végén jelenik meg Rómában, egyes kutatók a praenestei Fortuna Primigeneiával azonosítják, ez azonban meggyőzően nem bizonyítható. A Fortuna Publica azonosításával kapcsolatos problémákról ld. MiANO (2018: 115-121). Mivel Spoletium latin colonia volt, elképzelhető, hogy tisztelete emiatt honosodott meg ott.

79 341-től kezdve számos rendelkezés tiltotta a nyilvános áldozatbemutatást (vö. Cod. Theod. 16, 10, 2; 4; 5 etc.) súlyos büntetések kilátásba helyezésével, ennek ellenére azok továbbra sem maradtak abba. Az áldozati állatot egyetlen csapással kellett leölni, majd ezt követően a béljósok megvizsgálták azok zsigereit. Amennyiben azokat rendben találták, elkezdődhetett az állat feldarabolása és további feldolgozása, ha azonban a zsigereken olyan elváltozásokat tapasztaltak, amelyek baljós előjelnek minősültek, akkor meg kellett ismételni az áldozatbemutatást. A témáról bővebben ld. BEARDNORTH-PRICE (1998: 36-38). Plutarchos azt állítja, hogy saját korában a rómaiak „harmincszor ismételtek meg egy áldozatot, mert mindig azt gondolták, hogy valami hiba vagy figyelmetlenség történt." (Coriolanus 25, ford. MÁTHÉ Elek).

$80 \mathrm{Az}$ eredeti szövegben itt a remedia divina („,isteni orvosságok”) kifejezés szerepel, amellyel a bajelhárítás céljából végzett engesztelő szertartásokra utaltak.

${ }^{81}$ Symmachus apja 376-ban halt meg, a levélnek ez előtt kellett íródnia.
} 
hogy nekem és atyámnak egy és ugyanazon rövid levelet küldted el. ${ }^{82}$ Nem tartasz méltónak bennünket egy-egy külön oldalra? 2. „Neked volt megtisztelő - mondod majd -, hogy szülődhöz csatlakozhattál." Más dolgok azok, amelyekben vele közösen vagy egyenlőként óhajtok részt venni, a szeretetben saját nevem alatt részeltessenek engem. Tartózkodj tehát a körlevelektől, s fejezd be a semmibevevésemet, amelyből rövidségre törekvésed ered! Azonban vigyáznom kell, ha hosszasan beszélek ezekről a dolgokról, nehogy terhesebb legyen neked panaszáradatom, mint nekem a te leveled szűkszavúsága. Már csak az van hátra, hogy kérjem az isteneket: minél előbb látogass meg ismét minket legnagyobb örömünkre. Könnyű lesz írásaid szófukarságát bőbeszédűséggel viszonozni. Ég veled!

\section{$1,51$. \\ Symmachus Agorius Praetextatushoz 360/365-385 előtt ${ }^{83}$}

Elhatároztuk, hogy október elsejéig ${ }^{84}$ a falakon kívül maradunk, azonban egy hírnök, aki arról értesített, hogy szülővárosunkat összeomlás fenyegeti, megváltoztatta terveinket, mivel számomra rút dolognak látszott közös bajok idején a saját biztonságommal törődni. ${ }^{85}$ Ráadásul a

82 Symmachus itt tréfásan korholja barátját, amiért felrúgva a levelezési etikett íratlan szabályait, azonos tartalmú levelet küldött neki és apjának, később viszont már más hangnemet üt meg, amikor Ambrosiusnak tesz megjegyzést arra, hogy ugyanazt az ajánlólevelet küldte el két különböző embernek. Ep. 3, 32: Fratres mei Dorotheus et Septimius laudabiles viri unam tuam epistulam pertulerunt. Sed mihi religio fuit istiusmodi captare compendium, ut et tibi geminata officii responderet usura, et singulis honor debiti testimonii proveniret.

${ }^{83}$ A datálásra vonatkozóan ld. az 56. és 59. jegyzeteket.

84 SALZMANN (2011: 109) szövegkiadásában az ad K. Oct. helyett az adhuc olvasat szerepel. ${ }^{85}$ Nem egyértelmü, hogy milyen közös bajokról beszél itt Symmachus. Elképzelhető, hogy Gratianus császár 383. augusztus 25-én bekövetkezett halálára és az utána kialakult helyzetre utal, de még valószínűbb, hogy arról az éhínségről van szó, amely 383 körül sújtotta Rómát. Eusigniushoz írott leveléből (Ep. 4, 74) kiderül, hogy Symmachus már egy évvel korábban, 382-ben tudta, hogy élelemhiány várható a következő évben, mivel az africai tartományokban nagyon rossz volt a termés, s ez aztán be is következett. 383-385 folyamán több levelében, s mint praefectus urbi több relatiójában is foglalkozik a problémával (Ep. 2, 6; 7; Rel. 9, 7; 18; 35; 37). Nicomachus Flavianushoz szóló levelében éppúgy, mint itt az in communis malis kifejezést használja egy, az ittenihez hasonló tartalmú mondatban. (Ep. 2, 7, 2: Haec ego, non ut celerem reditum tibi suadeam, 
szent hivatal, a papi szolgálat gondoskodást kíván részemről, s főként a nekem kijelölt hónap kötelezettsége. ${ }^{86} \mathrm{Nem}$ visz rá a lélek, hogy - amikor ekkora a nemtörődömség a papok között - egy kollégát kérjek fel a helyettesítésre. Egykor a vallással kapcsolatos feladatok átadása egyszerü volt, most az oltároktól való távolmaradás a rómaiak számára a szavazatszerzés egy nemének számít. ${ }^{87} \mathrm{~S}$ téged meddig tart még vissza Etruria? ${ }^{88}$ Ezúttal neheztelünk amiatt, hogy oly hosszú időn keresztül a

sed ut noveris in communibus malis nihil esse quod proferas.) Híres 3. relatiójában összekapcsolja az éhínséget azzal, hogy a Vesta-szüzektől megvonták az állami támogatást: Rel. 3, 15-17: „Senki se gondolja, hogy a vallás ügye az egyetlen gondom: az ilyenfajta sérelmek okai minden csapásnak, ami a római népet sújtotta. Őseink törvénye szerény ellátással és méltányos kiváltságokkal tisztelte meg a Vesta-szüzeket és az istenek papjait. Épségben is volt ez az állami ellátás mindaddig, amíg az elvetemedett pénzváltók gyalázatos uzsorakölcsöneikkel föl nem emésztették a Vesta-szüzek eltartására rendelt kegyes alapítványokat: ennek a gazságnak a büntetése volt az általános éhínség és a rossz termés, amely valamennyi tartomány reményeit meghazudtolta. Nem a föld volt ennek az oka, nem foghatjuk rá a szelekre, nem üszög ártott a vetéseknek, nem gaz fojtotta meg a tiszta búzát: a szentségtörés miatt ment tönkre a termés. Mert el kellett pusztulnia mindennek, amit megvontak a vallási intézményektől. S ha kell még példa erre a csapásra, s a rettenetes éhínséget bizonyára a sivár esztendőknek tulajdoníthatjuk: súlyos ok idézte elő ezt a terméketlenséget. Most aztán megint erdei bogyókkal tengetik életüket, s az ínséges falusi nép megint a tölgyfák makkjára fanyalodott. Szenvedtek-e ilyen csapást a tartományok akkor, amikor a vallás papjait az állam megbecsülte és eltartotta? Mikor rázták le a makkot emberi táplálékul, mikor szaggatták ki a füvek gyökereit, mikor hagyta cserben az ínséges tartományt a másik, amelynek bő termése volt: amíg a néppel együtt a szent szüzeknek is megvolt a gabonájuk? Szívesen adták a föld termését, hiszen a papok táplálkozása inkább csak koplalás volt, mint dúskálkodás. Ugyebár nem kétséges, hogy mindig mindenkinek bőségesen jutott minden, amire most az általános ínségben hiába sóvárognak." (Ford. BORZSÁK István). Mindazokat a római papságot és az ősi kultuszokat hátrányosan érintő intézkedéseket, amelyeket Symmachus említ (ideértve a Victoria-oltár eltávolítását a senatus ülésterméből), Gratianus rendelte el 382-ben, így érthető, hogy a császár halálát követően feléledt a remény a régi vallás híveiben a „szentségtörés” elhárítására.

86 Valószínűleg a késő antikvitásra kialakult az a szokás, miszerint a pontifexek felosztották egymás között a teendőket oly módon, hogy minden hónapban két előre kijelölt főpap intézte az aktuális kötelezettségeket. Vö. SALZMANN (2011: 108-109).

87 Egyértelmű utalás az ősi vallás hanyatlására és a krisztianizálódási folyamat erősödésére.

88 Praetextatus etruriai kötődésére utal az is, hogy 362-ben a corrector Tusciae et Umbriae hivatalát töltötte be. 2010 és 2016 között egy nagyszabású ásatás keretében hatalmas 
polgártársaid elébe helyezel valamit. Legyen bár a vidéken tartózkodás kellemesebb, nem tudja jól élvezni a nyugalmat, aki távollevő szeretteiért aggódik. Ég veled!

\section{$1,52$. \\ Symmachus Agorius Praetextatushoz \\ 376}

Mindennél jobban örülök annak, hogy tetszik neked a beszédem, ${ }^{89} \mathrm{mi}-$ ként annak is, hogy az emberi nem jobbik része, a senatus kedvező véleménnyel fogadta. Még tetézted esküd súlyával, sőt szabályszerü esküvést tettél, jóllehet tudod, hogy szeretteink ítélete a kedvezés gyanúját veti föl. Ahol ugyanis biztos a barátság, ott bizonytalanabb a dicséret hitele. Megnyugodva tehát a te bírálatod felől, a többiek véleményével nem foglalkozom. Mi lett volna, ha te, aki ennyire jó szándékkal vagy irántam, ott lettél volna, hogy meghallgass? Ahogyan mondani szokás, ujjammal megérintettem volna az égboltot. ${ }^{90}$ Talán máskor kedvezőbb alkalom lesz majd a jelenlétedre. Most élvezzük azt a tetszésnyilvánítást, amit leveled tanúsít, akkor pedig majd kihasználjuk jóindulatod segítségét. Ég veled!

alapterületű, fényűző késő római villa maradványait tárták fel Etruria szívében, Capraia e Limite településen (Vincitől néhány kilométerre). Az előkerült számos lelet között volt egy felirattöredék Praetextatus nevével, amely azt valószínűsíti, hogy a villa a Vettius-család birtokában volt. A Villa dei Vetti vagy Villa dell'Oratorio néven emlegetett épületkomplexum területén több, rendkívül jó állapotban konzerválódott, kvalitásos mozaikot találtak a régészek, legnagyobb ismertségre közülük - kidolgozottságának magas művészi színvonala miatt - az a darab tett szert, amely egy vadkanvadászat jelenetét ábrázolja, s amelyhez foghatóak, az ásatásokat vezető Federico Cantini szerint, a korban csak Róma városában és Konstantinápolyban voltak. A részletes beszámolót az ásatások eredményeiről ld. CANTINI (2017).

${ }^{89}$ Arról a beszédről van szó, amelyet Symmachus az Ep. 1, 44, 2-ben említ, vö. a paragrafushoz tartozó jegyzeteket is.

${ }^{90}$ Ne ego digito, ut aiunt, supera convexa tetigissem. - A mondásra vö. Cic. Att. 2, 1, 7; Ov. Pont. 2, 2, 10; Prop. 1, 8, 43; Gaius Inst. 3, 98. 


\section{$1,53$. \\ Symmachus Agorius Praetextatushoz \\ 385 előtt $^{91}$}

1. Dicsekszel a pihenéssel és a vadászattal. Bizony ez mulatságos hencegés, de inkább tréfából állhattál elő vele, mint komolyan. Mivel szívesebben töltöd a pihenőidőt és a közfeladatoktól mentes ünnepnapokat a régiek könyvein kérődzve. ${ }^{92}$ Becsaphatsz tehát másokat, akik csak felületesen ismernek, én azonban nekem küldött leveleid zamatából sejtem, hogy miféle tevékenységek azok, amikkel éjjel-nappal foglalkozol, csakúgy, mint azt, hogy mi szellemed mindennapi tápláléka. 2. Hacsak nem Apollóval találkozol az erdőkben, mint hajdan a pásztor Hesiodus, akit költői babérral koszorúzott meg a Múzsák családja. ${ }^{93}$ Honnan erednek tudniillik leveleidben ezek az újszerü gondolatok, honnan a régies szavak, ha a fennköltebb dolgokról megfeledkezve, csak a csomós hálókkal, tollas vadijesztőkkel, ${ }^{94}$ jó szimatú kopókkal, s úgy általában a vadászat mesterségével törődsz? Ezért amikor írsz, ne felejts el mértéket szabni ékesszólásodnak. Legyen beszéded egyszerü és csiszolatlan, hátha úgy elhiszik rólad, hogy vadász vagy. Ég veled!

\footnotetext{
${ }^{91}$ A datálásra vonatkozóan ld. az 56. jegyzetet.

92 libris veterum ruminandis - A tréfás kifejezéssel Praetextatusnak a klasszikus irodalom és filozófia iránti szenvedélyére utal a szerző, s talán kommentárok készítésére is gondolhatunk a rumino ige alapján. A levél egyébként - mint később látni fogjuk - barátja írásainak méltatása: a tartalom újdonságának és az archaizmusok alkalmazásának kettőssége lenyűgözi Symmachust. Hasonló módon élcelődik később egy Valerianus nevü barátjával, aki azt állította, hogy kertészkedik: Ep. 8, 69: Rusticari te adseris et ducendis vitibus aut arboribus inserendis crudam senectutem fovere. Non hoc litterae tuae sapiunt, nisi forte Gallia tua dedux Heliconis.

93 Vö. Hes. Theog. 30; Verg. Ecl. 6, 69-70.

94 pinnarum formidines - A vadászok a kerítőhálóra színes (leginkább vörös) madártollakat aggattak a vadak megijesztése céljából, ezt a tollas kerítőhálót nevezték formidónak. Vö. Verg. Georg. 3, 372; Aen. 12, 750.
} 


\section{1,54 . \\ Symmachus Agorius Praetextatushoz \\ 380}

Nagy vigaszt nyújtottál bánatomra. Mert, ahogy a szóbeszéd már jelezte neked, testvérem halálától ${ }^{95}$ megsebezve folytonos szívfájdalom gyötör. Azonban jelenlegi gondjaim közepette igen nagy megkönnyebbülést jelentett nekem, hogy megtudtam: te magad - mindannyiunk óhajának megfelelően - jó egészségben vagy. Már csak az van hátra, hogy kegyeskedj gyakrabban időt fordítani az ilyesfajta feladatokra, amelyek, mint látod, szerencsétlenségemre és gyászomra valamiféle orvosságként szolgálnak nekem. Ég veled!

\section{1,55 . \\ Symmachus Agorius Praetextatushoz}

384

Tudom, hogy testvéri szeretetből196 fakad, amit javasolsz. Azonban a kibékülést annak kell kezdeményeznie, aki az indokolatlan nézeteltérést okozta, ${ }^{97}$ nehogy olyan benyomás keletkezzék: megérdemelt büntetést kapott az, aki a megtagadott barátságot úgy törekszik feléleszteni, mint-

\footnotetext{
95 Symmachus szeretett testvére, a 46. levélben már említett Celsinus Titianus 380 késő tavaszán vagy nyarán halt meg. A szónok bánatára Praetextatustól remél vigasztalást, ami barátságuk bensőséges jellegét erősíti. Testvére elvesztése mélyen megrendítette Symmachust, gyászának megnyilvánulásaival más leveleiben is találkozunk. A Hesperiushoz szóló levelében $(E p .1,83)$ a következőket írja: Nec puto ignorare te, quatenus in nos fortuna saevierit, quae me amantissimo atque optimo fratre privavit. A Flavius Syagrius consullá választása alkalmából tartott beiktatási ceremónián (381. január 1.) való részvételét is azért mondja le, mert úgy érzi, időre van még szüksége a gyász feldolgozásához (Ep. 1, 101, valamint ehhez kapcsolódik az Ep. 3, 21, amelyben Gregorius nevü barátjával tudatja az ünnepségről való távolmaradása okát: Neque enim fas sinit laeta officia obire lugentes. Hasonlóképpen menti ki magát egy ismeretlen címzetthez szóló levelében is, Ep. 9, 103, 2: Nam mihi turpe atque inpetibile est adtonito animo et fronte maesta laetos adire conventus.). Ld. még Ep. 3, 6- ahol három fivére elvesztéséről beszél.

${ }_{96}$ A családias kötelékre utaló kifejezéssel Symmachus itt is a szoros barátságot kívánja érzékeltetni.

${ }^{97}$ Nem tudjuk, kivel volt Symmachusnak nézeteltérése és milyen okból, de szavai alapján úgy látszik, nem jelentéktelen problémát okozott számára ez a dolog. Az ügyben Praetextatus közvetítőként léphetett fel a két fél között.
} 
ha ő maga semmit se szenvedett volna. Ezért nem utasítom vissza a felajánlott kiegyezést, azonban az állítsa helyre - tekintet nélkül a körülményekre - a jó egyetértést, aki a támadást indította.

Barátságunk nevében sok szerencsét kívánok neked, aki tevékenységeddel a közjót fogod szolgálni. ${ }^{98}$ Erről egyelőre kevesebbet beszélek, ugyanis az olyan dolog, amely mindenkit érint, sosem elégszik meg egyetlen tanúval, s részemről egyébként is az a leginkább helyénvaló, ha így idézem fel dicsőségedet, nehogy azt gondolják rólam, megfeledkeztem a rád jellemző szerénységről. Ég veled!

\section{Felhasznált irodalom}

BEARD-NORTH-PRICE 1998

M. BEARD - J. NORTH - S. PRICE, Religions of Rome, vol. I., Cambridge, 1998.

CALLU 2003

J.-P. CALLU (ed., trad.), Symmaque, Correspondance, Tome I, Livres I et II, Paris, 2003.

CANTINI 2017 F. CANTINI et al., La villa dei "Vetti” (Capraia e Limite, FI): Archeologia di una grande residenza aristocratica nel Valdarno tardoantico, Archeologia Medievale 44 (2017), 9-71.

FlamANT 1977 J. Flamant, Macrobe et le néo-platonisme latin, à la fin du IVe siècle, Leiden, 1977.

KaHLOS 1994 M. KAHLOS, Fabia Aconia Paulina and the Death of Praetextatus: Rhetoric and Ideals in Late Antiquity (CIL VI 1779), Arctos 28 (1994), 13-25.

KaHlos 1995 M. KAHLOS, The Restoration Policy of Vettius Agorius Praetextatus, Arctos 29 (1995), 39-48.

KAHLOS 1997 M. KAHLOS, Vettius Agorius Praetextatus and the Rivalry between the Bishops in Rome in 366-367, Arctos 31 (1997), 41-54.

KAHLOS 2002 M. KAHLOS, Vettius Agorius Praetextatus: A Senatorial Life in Between, Helsinki, 2002.

Kelly 2013 G. Kelly, The Political Crisis of AD 375-376, Chiron 43 (2013), 357-409.

KOHNS 1961 H. P. KOHNS, Versorgungskrisen und Hungerrevolten im spätantiken Rom, Antiquitas 1, Abhandlungen zur alten Geschichte 6, Bonn, 1961.

\footnotetext{
98 Minden bizonnyal Praetextatus praefectus praetorióvá történő kinevezése indokolja a jókívánságokat. Ez az esemény datálja a levelet 384-re, amely év májusától decemberben bekövetkezett haláláig látta el Praetextatus ezt a hivatalt. E magas tisztségre utalhat a szöveg további részében a dicsőség emlegetése is. Ugyanebben az évben Symmachus töltötte be a praefectus urbi hivatalát, s feltételezhetően ebbéli minőségében támadt valakivel az a konfliktusa, amelyről az első bekezdésben beszél.
} 
LIZZI TESTA 2004 R. LIZZI TESTA, Senatori, popolo, papi: Il governo di Roma al tempo dei Valentiniani, Bari, 2004.

MACHADO 2006 C. MACHADO, Building the Past: Monuments and Memory in the Forum Romanum, in: W. Bowden - A. Gutteridge - C. Machado (eds.), Social and Political Life in Late Antiquity (Late Antique Archeology vol. 3. 1), Leiden - Boston, 2006, 157-194.

MattheWs 1975 J. MatTHeWs, Western Aristocracies and Imperial Court A. D. 364-425, Oxford, 1975.

MiAno 2018 D. MiAno, Fortuna. Deity and Concept in Archaic and Republican Italy, Oxford, 2018.

Mitchell 2016 J. MitchelL, The Religious World of Quintus Aurelius Symmachus, (A thesis submitted to the University of Wales Trinity Saint David), 2016. URL: https://bit.ly/QuintAurSym

SALZMAN-ROBERTS 2011

M. R. SALZMAN (transl., intr., comm.) - M. ROBERTS (transl.), The Letters of Symmachus: Book 1 (Writings from the Greco-Roman World), Atlanta, 2011.

SEECK 1883

O. SEECK, Q. Aurelii Symmachi opera quae supersunt, Berlin, 1883.

TÓTH 2020

TóTH O., Symmachus: Levelek. Első könyv 1-12, Antikvitás \& Reneszánsz 6 (2020), 179-202.

WATTS 2015 E. J. WATTS, The Final Pagan Generation, Oakland, 2015. 